\title{
Targeted Therapy of FLT3 in Treatment of AML-Current Status and Future Directions
}

\section{Caroline Benedicte Nitter Engen ${ }^{1}$, Line Wergeland ${ }^{1}$, Jørn Skavland ${ }^{1}$ and Bjørn Tore Gjertsen ${ }^{1,2, *}$}

1 Center for Cancer Biomarkers CCBIO, Department of Clinical Science, University of Bergen, Bergen N-5020, Norway; E-Mails: caroline.engen@k2.uib.no (C.B.N.E.); line@wergeland.jacobsen.net (L.W.); jorn.skavland@k2.uib.no (J.S.)

2 Department of Internal Medicine, Hematology Section, Haukeland University Hospital, Bergen N-5021, Norway

* Author to whom correspondence should be addressed; E-Mail: bjorn.gjertsen@uib.no; Tel.: +47-55-97-29-68; Fax: +47-55-97-29-50.

External Editor: Celalettin Ustun

Received: 21 September 2014; in revised form: 27 November 2014 / Accepted: 28 November 2014 / Published: 15 December 2014

\begin{abstract}
Internal tandem duplications (ITDs) of the gene encoding the Fms-Like Tyrosine kinase-3 (FLT3) receptor are present in approximately $25 \%$ of patients with acute myeloid leukemia (AML). The mutation is associated with poor prognosis, and the aberrant protein product has been hypothesized as an attractive therapeutic target. Various tyrosine kinase inhibitors (TKIs) have been developed targeting FLT3, but in spite of initial optimism the first generation TKIs tested in clinical studies generally induce only partial and transient hematological responses. The limited treatment efficacy generally observed may be explained by numerous factors; extensively pretreated and high risk cohorts, suboptimal pharmacodynamic and pharmacokinetic properties of the compounds, acquired TKI resistance, or the possible fact that inhibition of mutated FLT3 alone is not sufficient to avoid disease progression. The second-generation agent quizartinb is showing promising outcomes and seems better tolerated and with less toxic effects than traditional chemotherapeutic agents. Therefore, new generations of TKIs might be feasible for use in combination therapy or in a salvage setting in selected patients. Here, we sum up experiences so far, and we discuss the future outlook of targeting dysregulated FLT3 signaling in the treatment of AML.
\end{abstract}


Keywords: acute myeloid leukemia; FLT3; tyrosine kinase inhibitors; clinical trials

\section{Introduction}

\subsection{Acute Myeloid Leukemia}

Acute myeloid leukemia (AML) is the most frequent acute leukemia in adults [1,2]. It is a heterogeneous clonal disorder of the myeloid precursor cells [3], and although patients today are treated with similar nonspecific treatment regimens that have remained more or less unchanged for decades [4-6], it has for an equally long period been recognized that there is considerable genetic, biological, and clinical heterogeneity in the patient group $[7,8]$. This variation is clearly reflected in the diverging relapse rate and overall survival in response to standard of care, ranging from $10 \%-70 \%$, dependent on both patient and disease related factors $[9,10]$. Current risk stratification at the time of diagnosis usually include age, performance status, white blood cell count, determining if the disease is de novo, secondary or therapy related, cytogenetics, and mutation analysis [11]. Several cytogenetic [12,13], molecular genetic (e.g., Fms-Like Tyrosine kinase-3 (FLT3), nucleophosmin 1 (NPM1), CCAAT enhancer-binding protein- $\alpha$ (CEBPA) [14], and epigenetic changes [15], as well as aberrantly expressed RNA, and microRNA [16] have been identified as prognostic markers for disease outcome, and as shown in other hematological malignancies it is thought that some of these changes represent feasible therapy targets. The challenge we are facing today is to translate this knowledge into tailored treatment for AML, identifying and directing the treatment towards cancer-specific pathways aiming for improved patient outcome.

\subsection{Mutations and Signaling Pathways in AML}

Normal hematopoiesis is controlled by the microenvironment and external signaling molecules, transmitting signals through intracellular signal transduction pathways via cell surface receptors. These intracellular pathways form a highly complex network of signaling cascades, including receptors, kinases, phosphatases and transcription factors that cross-talk extensively on multiple levels. Changes in this network by cytogenetic abnormalities, mutations or epigenetic alterations may lead to non-functional or hyper-activated pathways, that in turn can lead to anti-apoptosis and increased proliferation of the cells $[17,18]$.

The group of genes most frequently mutated in AML is signaling genes, including genes coding for receptor tyrosine kinases such as FLT3 and KIT, Serine-Threonine kinases, KRAS/NRAS and protein tyrosine phosphatases [19]. Aberrant regulation of intracellular signaling pathways accordingly appears to be an important leukemia promoting mechanism, and like inhibition of Bcr-Abl revolutionized patient outcome in chronic myeloid leukemia [20], targeting signaling onco-proteins seems like a feasible strategy in AML [21].

The one most frequent mutated gene in AML, with mutations detected in up to $35 \%$ of the patients, is the Fms-Like Tyrosine kinase-3 (FLT3) gene on chromosome 13q12. Two major classes of FLT3 mutations have been identified: length mutations, predominantly internal tandem duplications (ITD) in 
the juxtamembrane domain of FLT3, first described by Nakao et al. in 1996 [22], and tyrosine kinase domain (TKD) point mutations [23,24]. ITDs are detected in 20\%-25\% of AML patients, while about $5 \%-10 \%$ of patients have point mutations within the TKD, with a mutation at codon 835 being the most frequent one [22-24].

\subsection{Aberrant FLT3 Activation in AML}

FLT3 is a member of the tyrosine kinase III family and functions as a membrane bound growth factor receptor, usually expressed by human hematopoietic progenitor cells [25]. Binding of its ligand, FLT3-ligand (FL) induces a conformational change in the protein that causes activation of the intrinsic tyrosine kinase domain. The enzyme phosphorylates intracellular molecules and consequently activates multiple downstream signaling pathways involved in cellular survival, proliferation and differentiation [26]. The expression of FLT3 is normally lost upon differentiation [27,28], but as AML is caused by a block in differentiation and uncontrolled proliferation of the myeloid progenitor cells the expression is frequently "captured" in many AML blasts, and remains highly expressed in most AML cases [29,30]. While overexpression of the receptor has been associated with poor prognosis [31], the presence of FLT3-ITD mutations confers even stronger independent prognostic information as it significantly correlates with an increased risk of relapse and dismal overall survival, in comparison to the TKD mutation where such an associations is absent [32-34]. Although FLT3-ITD positive AML is not considered a distinct entity of AML, FLT3-ITD status has been included in the WHO 2008 guidelines and the European LeukemiaNet recommendations for classification of AML, providing important prognostic information [11,35]. The survival advantage of leukemic blasts driven by mutant FLT3 is to a large extent thought to be explained by a constitutive activation of the receptor causing FL independent autophosphorylation [36], and initiation of two major intracellular pathways essential for growth, survival and proliferation; PI3K/AKT/mTOR and RAS/RAF/MEK/ERK [37]. The signal transducers and activators of transcription (STATs) are usually not regulated via RTKs, but for mutations like FLT3-ITD a constitutive phosphorylation and transcriptional activation of STAT5 also occur [38,39].

With aberrant signaling appearing as a key component in FLT3-ITD mutated AML the constitutive active surface protein stands out as an attractive target for small molecule receptor inhibitor-based therapy [40,41]. Over the 15 years since the discovery of the mutated receptor and its clinical significance, more than a dozen different tyrosine kinase inhibitors (TKI) have been developed and tested preclinically, and many have shown to selectively induce cell death in FLT3 mutated AML blasts by suppressing FLT3 autophosphorylation and downstream signaling pathways [40-42]. Several of the agents, including the first generation agents lestaurtinib, linifanib, midostaurin, semaxanib, sorafenib, sunitinib, and tandutinib as well as the second generation agent quizartinib, have reached clinical trials where their safety, tolerability, and efficiency have been assessed. In the following section we will discuss and compare the most relevant FLT3 TKIs in clinical trials. Both trials where the TKIs are used as monotherapy and trials where conventional treatment is combined with a TKI will be assessed and summarized, with focus on antileukemic efficacy and side effects (Table 1). 
Table 1. Overview of evaluated clinical trials.

\begin{tabular}{|c|c|c|c|c|c|c|c|c|c|}
\hline Agent & Study Phase & Patient Population & $n$ & $\begin{array}{c}\text { Median/Mean } \\
\text { Age (years) } \\
\end{array}$ & FLT3-ITD & $\begin{array}{c}\text { FLT3-Point-Mutation } \\
\text { Only } \\
\end{array}$ & Treatment & Dose & Ref. \\
\hline \multirow{3}{*}{$\begin{array}{c}\text { Lestaurtinib- } \\
\text { CEP-701 }\end{array}$} & Phase $1 / 2$ & AML, refractory/relapsed & 17 & $61(18-71)$ & $94.1 \%(n=16)$ & $5.9 \%(n=1)$ & Monotherapy & $40 \mathrm{mg}-80 \mathrm{mg} \times 2$ & [43] \\
\hline & Phase 2 & AML, untreated & 29 & $73(67-82)$ & $6.9 \%(n=2)$ & $10.3 \%(n=3)$ & Monotherapy & $60 \mathrm{mg}-80 \mathrm{mg} \times 2$ & [44] \\
\hline & $\begin{array}{c}\text { Phase } 2 \\
\text { (Randomized) }\end{array}$ & AML, first relapse & 224 & $56.5(20-81)$ & $92 \%(n=206)$ & $7.6 \%(n=17)$ & $\begin{array}{c}\text { + Mitoxantrone, Etopside \& } \\
\text { Cytarabine }\end{array}$ & $80 \mathrm{mg} \times 2$ & {$[45]$} \\
\hline $\begin{array}{c}\text { Linifanib- } \\
\text { ABT-869 }\end{array}$ & Phase 1 & AML, refractory/relapsed & 47 & $56.3(23-81)$ & $12.8 \%(n=6)$ & $10.6 \%(n=5)$ & Monotherapy/+ Cytarabine & $5-25 \mathrm{mg}$ & [46] \\
\hline \multirow{3}{*}{$\begin{array}{c}\text { Midostaurin- } \\
\text { PKC412 }\end{array}$} & Phase 2 & $\begin{array}{c}\text { AML, refractory/relapsed, } \\
\text { High risk MDS }\end{array}$ & 20 & $62(29-78)$ & $90 \%(n=18)$ & $10 \%(n=2)$ & Monotherapy & $75 \mathrm{mg} \times 3$ & {$[47]$} \\
\hline & Phase 2B & $\begin{array}{c}\text { AML, refractory/relapsed, } \\
\text { High risk MDS }\end{array}$ & 95 & $64 \% \geq 65$ years & $27.4 \%(n=26)$ & $9.5 \%(n=9)$ & Monotherapy & $50 \mathrm{mg}-100 \mathrm{mg} \times 2$ & [48] \\
\hline & Phase IB & AML, untreated & 69 & 48.5 & $17.4 \%(n=12)$ & $8.7 \%(n=6)$ & + Daunorubicin \& Cytarabine & $50 \mathrm{mg}-100 \mathrm{mg} \times 2$ & [49] \\
\hline \multirow{3}{*}{$\begin{array}{c}\text { Semaxanib- } \\
\text { SU5416 }\end{array}$} & Phase 2 & $\begin{array}{c}\text { AML, refractory or } \\
\text { advanced, High risk MDS }\end{array}$ & 33 & $64(23-76)$ & $4.5 \%(n=1 / 22)$ & NA & Monotherapy & $145 \mathrm{mg} / \mathrm{m}^{2}$, twice weekly & {$[50]$} \\
\hline & Phase 2 & AML advanced, c-kit pos. & 43 & $65(27-79)$ & $20 \%(n=7 / 35)$ & NA & Monotherapy & $145 \mathrm{mg} / \mathrm{m}^{2}$, twice weekly & {$[51]$} \\
\hline & Phase 2 & $\begin{array}{l}\text { AML refractory, } \\
\text { High risk MDS }\end{array}$ & 55 & $64-66(22-80)$ & NA & NA & Monotherapy & $145 \mathrm{mg} / \mathrm{m}^{2}$, twice weekly & {$[52]$} \\
\hline \multirow{5}{*}{$\begin{array}{l}\text { Sorafanib- } \\
\text { BAY 43-9006 }\end{array}$} & Phase 1 & AML, refractory/relapsed & 16 & $61.5(48-81)$ & $43.8 \%(n=7)$ & $12.5 \%(n=2)$ & Monotherapy & $200 \mathrm{mg}-600 \mathrm{mg} \times 2$ & {$[53]$} \\
\hline & Phase 1 & $\begin{array}{c}\text { AML refractory/relapsed, } \\
\text { High risk MDS }\end{array}$ & 42 & 71.3 & $33 \%(n=9 / 27)$ & NA & Monotherapy & $100 \mathrm{mg}-400 \mathrm{mg} \times 2$ & {$[54]$} \\
\hline & $\begin{array}{c}\text { Phase } 2 \\
\text { (Randomized) }\end{array}$ & AML,$>60$ years & 197 & $68(61-80)$ & $14 \%$ & NA & $\begin{array}{l}+ \text { Cytarabin and } \\
\text { Daunorubicun }\end{array}$ & $400 \mathrm{mg} \times 2$ & {$[55]$} \\
\hline & Phase 1 & $\begin{array}{l}\text { Acute leukemia, } \\
\text { refractory/relapsed }\end{array}$ & 12 & $9.5(6-17)$ & $41.7 \%(n=5)$ & NA & + Clofarabine \& Cytarabine & $150 \mathrm{mg} / \mathrm{m}^{2} / 200 \mathrm{mg} / \mathrm{m}^{2} \times 2$ & {$[56]$} \\
\hline & Phase $1 / 2$ & AML, refractory/relapsed & 43 & $64(24-87)$ & $93 \%(n=40)$ & NA & +5 -Azacytidine & $400 \mathrm{mg} \times 2$ & [57] \\
\hline
\end{tabular}


Table 1. Cont.

\begin{tabular}{|c|c|c|c|c|c|c|c|c|c|}
\hline Agent & Study Phase & Patient Population & $n$ & $\begin{array}{c}\text { Median/Mean } \\
\text { Age (years) }\end{array}$ & FLT3-ITD & FLT3-Point-Mutation Only & Treatment & Dose & Ref. \\
\hline \multirow{2}{*}{$\begin{array}{c}\text { Sunitinib- } \\
\text { SU11248 }\end{array}$} & Phase 1 & AML & 29 & $67(19-82)$ & $10.3 \%(n=3)$ & $6.9 \%(n=2)$ & Monotherapy & $\begin{array}{c}50 \mathrm{mg}-350 \mathrm{mg} \text { as a } \\
\text { single dose }\end{array}$ & {$[58]$} \\
\hline & Phase 1 & AML, refractory & 15 & $72(54-80)$ & $14.3 \%(n=2 / 14)$ & $14.3 \%(n=2 / 14)$ & Monotherapy & $50 \mathrm{mg}-75 \mathrm{mg}$ & [59] \\
\hline $\begin{array}{c}\text { Tandutinib- } \\
\text { MLN-518 }\end{array}$ & Phase 1 & AML, High-risk MDS & 40 & $70.5(22-90)$ & $20 \%(n=8)$ & $2.5 \%(n=1)$ & Monotherapy & $50 \mathrm{mg}-700 \mathrm{mg} \times 2$ & {$[60]$} \\
\hline \multirow{7}{*}{$\begin{array}{c}\text { Quizartinib- } \\
\text { AC220 }\end{array}$} & Phase 1 & AML & 76 & $60(23-83)$ & $27 \%(n=18 / 65)$ & NA & Monotherapy & $12-450 \mathrm{mg} \times 1$ & {$[61]$} \\
\hline & Phase 2 & AML, refractory/relapse & 76 & $53(19-77)$ & $100 \%(n=76)$ & NA & Monotherapy & $30-60 \mathrm{mg}$ & {$[62]$} \\
\hline & Phase 2 & AML, refractory/relapse, unfit & 270 & $60.4(19-85)$ & $70.7 \%(n=191)$ & NA & Monotherapy & $90-135 \mathrm{mg}$ & {$[63,64]$} \\
\hline & & & & & & & + Cytarabin, & & \\
\hline & Phase 1 & AML, untreated $>60$ years old & 55 & $69(62-87)$ & $7.3 \%(n=4)$ & NA & Daunorubicin \& & $40-135 \mathrm{mg}$ & {$[65]$} \\
\hline & & & & & & & Etoposide & & \\
\hline & Phase 1 & $\begin{array}{c}\text { AML, MLL-rearranged ALL, } \\
>1 \text { month, } \leq 21 \text { years }\end{array}$ & 22 & NA & $27.3 \%(n=6)$ & NA & $\begin{array}{c}+ \text { Cytarabin \& } \\
\text { Etoposide }\end{array}$ & $25-60 \mathrm{mg} / \mathrm{m}^{2}$ & {$[66]$} \\
\hline
\end{tabular}




\section{Evaluation of Selected Small Molecule Inhibitors against FLT3 Used in Clinical Trials}

\subsection{First Generation TKIs}

\subsubsection{Lestaurtinib (CEP-701)}

Lestaurtinib is an orally bioavailable polyaromatic inolocarbazole alkoid compound that is synthetically derived from the bacterial fermentation product K-252a. It was originally identified as an inhibitor of the neurotropin receptor TrkA, and was initially studied in patients with solid tumors [42]. It has successively been found to be a potent FLT3 inhibitor, and has been investigated in AML patients [43-45]. In a phase 1/2 trial FLT3-mutated patients with advanced AML the drug was found to be generally well tolerated; with observed treatment related toxicities including mild nausea and emesis, and generalized weakness and fatigue. Clinical activity was observed in $29 \%$ of the patients during a limited time period, ranging from two weeks to three months. The drug significantly lowered peripheral blood blasts, and some patients had evidence of transient normal hematopoiesis [43]. In a phase 2 trial, lestaurtinib was administered in monotherapy as first-line treatment in 29 older AML patients not considered eligible for intensive chemotherapy. The drug was given for eight weeks, regardless of FLT3-mutation status. Observed toxicities included mild gastrointestinal side effects. No complete or partial remissions were seen, but transient reduction in bone marrow and peripheral-blood blasts was achieved in $60 \%(3 / 5)$ of the FLT3-mutated patients, compared to a $22.7 \%(5 / 22)$ response rate in the FLT3-wild-type group. The clinical response was however of short duration, with a median time to progression of 25 days [44]. In a bigger randomized phase 2 trial, 220 FLT3 mutated AML patients at first relapse received either chemotherapy alone or chemotherapy followed by lestaurtinib. There was no significant difference in the rate of adverse effects in the two groups, however, the seriousness of adverse effects was higher in the lestaurtinib-treated group. Of the patients receiving lestaurtinib $25.9 \%$ (29/112) patients achieved complete remission or complete remission with incomplete platelet recovery, compared to $20.5 \%(23 / 112)$ patients attaining equal treatment responses in the control group. There was however no significant difference in overall survival between the two groups, providing no clear benefit to adult AML patients with FLT3 mutations [45].

\subsubsection{Linifanib (ABT-869)}

Linifanib is an orally available potent inhibitor of FLT3 and VEGFR. Preclinically it has shown antileukemic effects both as monotherapy and in combination with cytarabine in FLT3-mutated human AML xenograft models [67]. In a phase 1 dose-escalation study, relapsed or refractory AML patients were treated either with linifanib alone or linifanib in combination with intermediate-dose cytarabine. Generally linifanib was well tolerated, and the most common side effects related to the treatment were fatigue, gastrointestinal distress and infections. The primary objective in the study did not include efficacy, but antileukemic effects were observed both in patients with FLT3 mutated as well as FLT3 wild-type patients [46]. 


\subsubsection{Midostaurin (PKC412, $N$-Benzoylstaurosporin)}

Midostaurin is a derivate of staurosporine, initially developed as a protein kinase $\mathrm{C}$ inhibitor, and extensively used as model agent for the study of apoptosis. It is a multi-targeting TKI, inhibiting tyrosine kinases such as c-Kit and PDGFR as well as FLT3 [68]. In a phase 2 trial FLT3 mutated patients with relapsed or refractory AML or high-risk MDS not considered candidates for chemotherapy, were treated with midostaurin in monotherapy. The drug was generally well tolerated with the most frequent treatment related adverse effect being nausea and vomiting. The drug showed some transient clinical activity, reducing the amount of peripheral blasts by $50 \%$ in $70 \%(14 / 20)$ of the patients, and reducing bone marrow blast counts by $50 \%$ in $30 \%(6 / 20)$ of the patients [47,69]. In a larger phase $2 \mathrm{~B}$ trial 95 AML/high risk MDS patients were randomized to receive either $50 \mathrm{mg}$ or $100 \mathrm{mg}$ of oral midostaurin twice daily, independently of FLT3 mutation status. Midostaturin was generally well tolerated in both concentrations and there were no clear difference in results according to dose regime. Side effects included nausea and vomiting. In the 92 patients, treatment efficiency could be assessed the reduction in peripheral blood or bone marrow blasts by $50 \%$ or more was $71 \%$ in the FLT3-mutated group compared to $42 \%$ in the FLT3-wild-type group. The majority of patients with FLT3-mutations responded with a reduction in blast count. One partial response was seen in a FLT3-ITD positive patient at the $100 \mathrm{mg}$ per day regime. Hematological improvement was seen in 46\% of the patients with FLT3-ITD versus 35\% of the FLT3-wild-type patients. All therapy naive FLT3-ITD patients had a clear reduction of peripheral blood and bone marrow blasts [48]. In a phase 1B study, 69 younger newly diagnosed AML patients were treated with midostaurin in addition to a standard of care regime consisting of daunorubicin and cytarabine. The treatment cycle run for 28 days with one group getting the inhibitor concomitant starting on day 1-7 and day 15-21 and a second group getting the inhibitor administered sequentially starting on day 8-21 with 14 treatment days per cycle. The first 29 patients received midostaurin $100 \mathrm{mg}$ orally twice daily. This dosage regime was discontinued because of adverse effects and followed by 40 AML patients who received midostaurin $50 \mathrm{mg}$ twice daily. The treatment at the $50 \mathrm{mg}$ twice-daily regime was generally well tolerated. The complete remission rate of the patients in the FLT mutant group $(n=18)$ and wild-type group $(n=51)$ was $92 \%$ and $74 \%$, respectively [49]. Initial results from a phase $1 / 2$ study of midostaurin and 5-Azacytinine in combination in refractory or relapsed AML demonstrates that it is a feasible alternative with a complete remission rate of $25 \%$, and additionally $20 \%$ of patients achieving complete remission with incomplete platelet recovery [70]. An additional phase 1 study of midostaurin, bortezomib and chemotherapy shows promising antileukemic activity in refractory/relapsed AML patients and further investigation is ongoing [71]. A larger placebo controlled phase 3 trial (ClinicalTrials.gov identifier: NCT00651261), comparing midostaurin in addition to standard induction therapy is currently in completion and may indicate the pathway forward for midostaurin in AML treatment.

\subsubsection{Semaxanib (SU5416)}

Semaxanib is an indolinone derivate that inhibits VEGFR, c-Kit and FLT3. It produces a dose dependent inhibition of tumor progress in a diversity of xenograft models, comprising malignant melanoma, glioma, fibrosarcoma and carcinomas of the lung, breast, prostate, and the skin [72]. In a 
phase 2 study of 33 patients, either with refractory AML or advanced MDS, the effect of semaxanib in monotherapy was assessed. Semaxanib was infused intravenously twice weekly in a dose of $145 \mathrm{mg} / \mathrm{m}^{2}$. Objective responses were seen in $18.2 \%$ (4/22) of the AML patients; three patients attained a partial response while one patient achieved a hematologic improvement [50]. In a second phase 2 trial, c-Kit positive patients with advanced AML were treated with semaxanib in monotherapy. Observed toxicities included nausea, musculoskeletal pain, headache, insomnia, vomiting, vertigo, fatigue/malaise, abdominal pain, sweating, and arthralgia. Half of the patients included in the study experienced severe adverse effects, with pneumonia and sepsis being the most frequent. Of the 25 patients evaluable for clinical response, no remissions were observed among the FLT3-ITD positive patients $(n=7)$. One patient achieved a morphologic remission while $28 \%(7 / 25)$ patients experienced a transient partial response with at least $50 \%$ reduction in bone marrow and peripheral blood blasts. The mean response duration of all eight responding patients was 1.6 months until disease progression. Patients with AML blasts expressing high levels of VEGF mRNA had a significantly higher response rate compared to the rest of the patient group, indicating that the main antileukemic effect was mediated by semaxanib's antiangiogenic properties rather than direct growth inhibition [51]. In a third phase 2 trial, 55 patients with refractory AML or advanced MDS were treated with semaxanib in monotherapy. Observed toxicities included headache, dyspnea, fatigue, thromboembolic events, bone pain and gastrointestinal events. Objective responses were obtained in $7.3 \%$ of the patients; three patients achieved partial responses and one patient experienced a hematologic improvement [52].

\subsubsection{Sorafenib (BAY 43-9006)}

Sorafenib is an orally available bi-aryl urea that inhibits several kinases, including RAF-kinase, VEGFR-2, c-Kit, and FLT3. It is currently approved for the treatment of metastatic renal cancer and advanced hepatocellular carcinoma [73]. In a phase 1 trial, refractory or relapsed AML patients were treated with sorafenib $200 \mathrm{mg}$ twice daily. A clinical response was seen in 56.3\% (9/16) of the patients, including all of the FLT3-ITD positive patients $(n=6)$. Both circulating and bone marrow blasts were strongly reduced in patients with FLT3-ITD mutation, while there was no essential change in the patients without FLT3-ITD [53]. In a randomized phase 1 clinical and biologic study of sorafenib, 42 patients with either AML or MDS were randomized either to continuously administration of the drug, or intermittent. The drug was administered twice daily, and the dose increased during the trial to evaluate dose-limiting toxicity. Of the patients assessed 33\% (9/27) were FLT3-ITD positive. Dose-limiting toxicity was prevalent at the $400 \mathrm{mg}$ twice-daily regime. The most seen drug related side effects were of gastrointestinal character, including abdominal pain, nausea, and vomiting. Palmar-plantar dysesthesia among other toxic skin reactions were also seen. Three patients experienced arterial thrombosis; myocardial infarction, brain stem infarction and splenic infarcts. One complete remission, lasting 2.7 months, was observed in a FLT3-ITD positive patient. In $33.3 \%$ of the FLT3-ITD positive patients, an improvement in peripheral blood and bone marrow blast counts was observed [54]. Recently, the results from a randomized, placebo-controlled trial concluded that the combination of standard induction treatment with sorafenib as consolidating treatment was of no benefit for AML patients older than 60 years of age compared to standard induction therapy alone. On the contrary, this combination seemed to cause worse outcomes with more adverse effects. Event-free survival and overall survival was not 
significantly improved, and these results were consistent also in the FLT3-ITD positive subgroup of patients [55]. Initial results from a similar study however indicated that the addition of sorafenib to standard chemotherapy is associated with a high rate of complete remission and an acceptable toxicity profile in FLT3-mutated older AML patients [74]. In a phase 1 pharmacokinetic and pharmacodynamic trial sorafenib was studied in concurrence with the cytotoxic agents clofarabine and cytarabine in pediatric acute myeloid leukemia patients, who all had either relapsed or refractory disease. All patients experienced hand-foot skin reactions and/or rash, which was also the dose-limiting toxicities, with maximum tolerated dose determined to $150 \mathrm{mg} / \mathrm{m}^{2}$ twice daily. On day 8, sorafenib decreased blast percentages in $83.3 \%$ (10/12) of the patients. After combination chemotherapy three of five patients with FLT3-ITD mutations and three FLT3-wild-type patients achieved complete remissions. One additional FLT3-wild-type patient with AML attained a partial remission [56]. A retrospective assessment of FLT3-ITD positive pediatric patients suggested that post-transplant therapy with sorafenib might also improve outcome in patients that have been treated with hematopoietic stem cell transplantation [75]. In a phase 2 trial, 43 AML patients, mainly FLT3-ITD positive (93\%), were treated with sorafenib in combination with 5-Azacytidine. Antileukemic efficacy was observed in $46 \%$ of the assessable patients, including a $27 \%$ complete remission rate [57].

\subsubsection{Sunitinib (SU11248)}

Sunitinib is an oral multi-targeting TKI, predominantly targeting PDGFR, VEGFR, c-Kit and FLT3. It has been used in treatment for multiple solid malignancies, and is approved for the treatment of metastatic renal cell carcinoma and gastrointestinal stromal tumors [76]. In a phase 1 clinical trial, 29 AML patients were treated with a single dose of sunitinib. The dose was escalated in $50 \mathrm{mg}$ increments from $50 \mathrm{mg}$ to a highest dose of $350 \mathrm{mg}$. Adverse effects occurred in $31 \%$ of patients reported at the 250-350 mg dose levels. The toxicities were mainly of mild gastrointestinal character, like diarrhea and nausea. Determination of clinical response was not a study target and was not assessed thoroughly. Peripheral blood blast counts were however analyzed at 24 and 48 hours after treatment and five patients exhibited a large decrease in blast count. Of these five patients, two had an FLT3-ITD mutation [58]. In a phase 1 study, 15 patients with refractory or resistant AML or patients not amenable for conventional therapy were treated with sunitinib in 4-week cycles at the starting dose of $50 \mathrm{mg}$, followed by $75 \mathrm{mg}$. In total, $33.3 \%$ of the patients were FLT3-mutated. Treatment related side effects were generally of mild character. At the $50 \mathrm{mg}$ treatment regime three patients experienced grade 2 adverse effects. One patient experienced lower limbs edema and fatigue, a second patient experienced taste disturbances and dry skin, and a third patient experienced fatigue, nausea and vomiting, tenesmus, mouth ulcerations, gingivitis, circulation disorders, hematuria, proteinuria and increased creatinine. Both patients treated with $75 \mathrm{mg}$ experienced dose limiting side effects. Forty percent of the patients experienced transitory morphologic or partial responses with reduction of the percentage of leukemic blasts in peripheral blood and bone marrow, including $100 \%$ of the patients within the FLT3-mutated group in comparison with $20 \%$ of the FLT3 wild-type patients [59]. 


\subsubsection{Tandutinib (MLN-518)}

Tandutinib is a piperazinyl quiazoline type III TKI with very limited inhibition of kinases outside this receptor family of FLT3, PDGFR and KIT [77]. In a phase 1 study, 40 patients were given tandutinib orally in doses ranging from $50 \mathrm{mg}$ to $700 \mathrm{mg}$ twice daily. The patients had either AML, or high-risk MDS. The most frequent toxicities associated with tandutinib treatment were nausea and vomiting, less frequent diarrhea and peripheral and periorbital edema. Muscular weakness and fatigue were the dose limiting toxicities, and were observed at dose levels of $525 \mathrm{mg}$ and $700 \mathrm{mg}$ twice daily. One patient experienced hyperreflexia with clonus. Preclinical evaluation of tandutinib suggested that it might prolong the QT interval, and one patient had a $270 \mathrm{~ms}$ increase of QT $\mathrm{c}$ on day 28. The QT interval however returned within normal range during continuous dosing. No complete or partial remissions were seen in this study. However, of the five patients with FLT3-ITD mutations that were assessed for treatment efficacy, antileukemic activity was shown in two patients. They both had a greater than $99 \%$ decrease in absolute peripheral blast count and a decrease in bone marrow blast percentage from $91 \%$ to $62 \%$ and $80 \%$ to $15 \%$ over the first 28 days of treatment. Within two months however they both experienced disease progression. Four patients without FLT3-ITD mutation sustained steady peripheral blood counts and bone marrow blast counts in periods ranging from 154-190 days [60].

\subsection{Second Generation TKIs}

Quizartinib (AC220)

Quizartinib is unique among FLT3 inhibitors currently in development, in that it combines high potency and high kinase selectivity with favorable pharmacokinetic properties, and it is currently suggested as the most promising FLT3 targeting TKI [78]. It showed promising results already in a phase 1 study [61], and the optimism has remained high until now. In a phase 2 study, quizartinib was administered as monotherapy in 333 relapsed or refractory AML patients. The most frequent experienced treatment-related adverse events were nausea, anemia, QT interval prolongation, vomiting, febrile neutropenia, diarrhea, and fatigue. Quizartinib seemed to reduce blasts in both FLT3-wild-type as well as FLT3-ITD positive patients, though more efficiently in FLT3-ITD positive patients, and the overall clinical response rates were high, however few complete remissions were seen $[63,64]$. Results from a phase 2 study assessing quizartinib as monotherapy comparing two different dosing scheduled confirm a high degree of antileukemic activity of quizartinib in FLT3-ITD positive AML patients with half of included patients achieving a hematological response, and as many as 33\% of patients were successfully bridged to hematological stem cell transplantation [62]. A pilot establishing that quizartinib safely can be combined with chemotherapy demonstrated a 79\% complete remission rate in evaluable patients [65]. Quizartinib in combination with cytarabine and etoposide was also assessed in 18 pediatric AML patients, either with relapsed or refractory disease. Eight of the patients were FLT3-ITD positive and of the six assessed four patients achieved complete remission or complete remission with incomplete platelet recovery [66]. 


\section{Discussion}

Current clinically established therapy regimes for AML mainly fail to achieve durable responses due to high relapse rates associated with development of drug resistance. Those patients who harbor a constitutively activating FLT3-ITD mutation have particular poor initial therapy response, high relapse rate, and inferior overall survival. Optimism was substantial when the therapeutic principle based on inhibition of FLT3 emerged, and multiple compounds have been developed and tested. Eight of the TKIs investigated in clinical trials have here been presented and the results of their clinical efficacy compared, including the first-generation agents; lestaurtinib, linifanib, midostaurin, semaxanib, sorafenib, sunitinib and tandutinib, as well as the second-generation TKI quizartinib. Though the various compounds diverge in degree of treatment responses as well as character and seriousness of adverse effects, they are generally well tolerated with less toxic effects than conventional chemotherapy provided in high or intermediate dose levels. However, TKIs seems only to induce modest clinical effects, including partial and transient responses, usually only in peripheral blasts.

There may be several reasons for why AML patients with FLT3-ITD mutations do not respond to treatment as anticipated. In the majority of the clinical trials, the treatment with TKIs were limited to patients with relapsed or refractory disease, or to patients not eligible for conventional treatment. The experience from this selected patient group might not be applicable to the group of newly diagnosed or younger AML patients.

In vivo inhibition of FLT3 autophosphorylation seems to be greatly associated with remission rate, and insufficient prolonged inhibitory drug levels might be another reasons for treatment failure [79]. Clinical response occurred in patients who sustained plasma FLT3 inhibitory activity and had an inherent sensitivity of blasts to the cytotoxic effects of lestaurtinib [44]. Several second generation TKIs, in addition to quizartinib, are under development, offering improved pharmacodynamic and pharmacokinetic properties including increased potency and selectivity towards FLT3-mutated cells [80]. VX-322 [81], BPR1J-097 [82], TT-3002 [83,84], AKN-028 and AKN-032 [85,86] are examples of novel FLT3 inhibitors that are showing promising in vitro and in vivo antileukemia activities.

Many of the compounds tested in clinical trials gave an initial response but of short duration before relapse, indicating development of resistance. Acquired point mutations in the molecular target of FLT3 in response to TKI treatment, precluding the drug from adequate binding appears to be an important mechanism in this process $[87,88]$. Aberrant activation of alternate growth and viability pathways is yet another possible mechanism for acquired resistance [89-91].

Unexpectedly, it was not so easy to predict who would benefit from the treatment as assumed. Not all FLT3-ITD positive patients responds to TKI therapy, while on the contrary some FLT3 wild-type patients seem to benefit from TKI treatment. Biomarkers predictive of therapy response are warranted. It is suggested that quizartinib does not induce complete remission, but decrease blast numbers with presence of dysplastic changes in the bone marrow [92]. In a small study of quizartinib-treated AML patients examined by mass spectrometric super-SILAC of phospho-protein, the team of Hubert Serve have indicated that a profile of four proteins may determine responders of quizartinib independent of FLT3-ITD [93]. This proposes phophoprotein profiling in prediction of therapy response, and may be transferred to a clinical diagnostics assay format like flow cytometric analysis of intracellular phosphoproteins [94]. 
Although FLT3 is a well-characterized oncoprotein in AML, and its role as an important player in AML leukemogenesis established, our knowledge of the normal and pathologic FLT3 signaling network may still be inadequate for identification of the most effective therapeutic approach, as there are many aspects of the mutation we do not fully comprehend.

An initial concern in the study of FLT3 in AML was the heterogeneity of the mutations, both the difference between point mutations and ITDs and within the group of ITDs. The mutation can appear in various lengths in the same patient, either simultaneously or over time, and in response to intensive chemotherapy the mutation can appear in previously FLT3-ITD negative patients, it can disappear or dramatically change at relapse [95-99]. The size of the ITD has been reported as a prognostic marker, with patients with a insertion of $48-60$ base pairs seems to have worse outcome compared to patients with shorter or longer insertions in one study [100], and with increasing size as a marker for poor outcome in another [101]. High mutational load measured by a high FLT3-ITD/FLT3wt ratio, indicative of loss of heterozygosity, has been associated with inferior outcome [102,103], as well as the site of the ITD insertion, with insertions within the tyrosine kinase domain-1 conferring unfavorable prognosis [104]. Also, the number of FLT3-ITD mutations affects disease outcome [105].

Methodological advances have recently shed further light to the complex interplay of events that contribute to AML leukemogenesis [106]. In addition to formerly well-characterized frequent cytogenetic lesions, next generation sequencing of AML patient material has revealed 23 recurrently mutated genes probable to be involved in AML pathogenesis. Based on patterns of co-occurring and mutually exclusive genetic lesions probable biological co-operations driving disease progression are emerging [19,107]. Additionally, mapping of variant allele frequencies makes it possible to assess the intra-tumor clonal hierarchy, while temporal assessment of leukemic cell populations makes it achievable to determine the clonal evolution and the sequential order of acquisition of somatic mutation during disease development and progression, from pre-leukemic hematopoietic stem cells to AML blasts [108-110]. Accumulating evidence indicate that mutations in the FLT3 gene are disease promoting rather than disease initiating events [111,112], and that mutant FLT3 cooperates with other oncogenes and aberrantly regulated proteins associated with AML, e.g., NPM1, DNMT3A [19], NUP98/NSD1 [113] DEP-1, PML-RAR and AXL [114-116]. The potency of the TKI alone may consequently not be the best measure for the antileukemic effect, and a multi-targeted therapeutic approach may rather be of potential clinical benefit, combining agents targeting cooperative lesions, inhibitors of alternate pathways, or targeting downstream signaling molecules. The superior efficiency of sorafenib compared to other inhibitors supports this theory, as the effect might be a result of sorafenib's ability to suppress the activity of multiple pathways [53]. The pathways that most frequently are activated, PI3K/AKT/mTOR and RAS/RAF/MEK/ERK, may be feasible to target with a combined inhibitor approach. Effective AKT/mTOR inhibitors and MEK/ERK inhibitors are in clinical trials [117,118]. FLT3-ITD is additionally shown to accumulate in the endoplasmic compartment of the cell [119], and may form intracellular signaling protein complexes that represent a different signaling context compared to transmembrane FLT3 signaling [120], that might also be important to take into consideration.

The nature of internal tandem duplication mimic damages in DNA repair caused by anthracyclines [121,122]. Clinical studies with increasing doses of daunorubicin suggested that this dose escalation was not beneficial in FLT3-ITD patients [123]. Additionally, a retrovirally induced mouse 
leukemia model comprising FLT3-ITD indicated that the FLT3-ITD responded to cytarabine but not anthracycline in a p53 dependent manner [124]. Additionally, excessive receptor tyrosine kinase activity has been associated with increased endogenous DNA damage [125], and FLT3-ITD is associated with high redox activity in the leukemic cells, also related to increased DNA damage [126]. In the discussion of driver and passenger role for FLT3-ITD, it is difficult to neglect the possibility that leukemia with FLT3-ITD may be created through a fundamental genomic instability. This genomic instability may be targeting the FLT3 gene due to structural DNA features through the myelopoiesis when FLT3 expression is modulated as function of differentiation. This predisposition of FLT3-ITD may make these leukemia cells particularly vulnerable for anthracyline therapy, generating more FLT3-ITD mutations when exposed for this topoisomerase II inhibitor. Together, these observations indicate that FLT3-ITD positive patients does not benefit from anthracycline therapy. If this is correct, a dramatic change in current AML therapy needs to be undertaken, since all current induction therapy include anthracycline.

Together, the proven high relapse rate in FLT3-ITD and the emerging speculations in an underlying mutational vulnerability in the FLT3 gene should spur investigators to develop non-genotoxic therapy in particular for FLT3-ITD positive AML patients.

\section{Concluding Remarks}

A fundamental question that remains unanswered is whether the fairly modest clinical activity of first generation FLT3 inhibitors can be improved through the second generation of TKIs, offering better pharmacodynamic and pharmacokinetic properties, or if the potential benefits of FLT3 inhibitors are essentially inadequate. We are still awaiting results from ongoing clinical trials investigating various combinations of TKIs in different subgroups of AML patients. The preliminary conclusion concerning the agents investigated is that their therapeutic efficiency is limited when administered in monotherapy. It seems like the FLT3 inhibitors currently in clinical trials will have to be used in conjunction with established treatment or in combination with additional targeted therapeutics to ultimately improve outcomes in AML patients with FLT3-ITD mutations. It is also to be decided in which phase of the treatment is should be used; as part of first line induction therapy, as consolidation or post-remission treatment or in a relapse or refractory setting.

If presence of FLT3-ITD is a marker for less effective anthracycline therapy, we will need to perform a difficult switch to alternative induction regimes in these patients. Future trials should explore targeting of downstream FLT3 signaling, particular signaling unique for FLT3-ITD, and with a clear strategy for blocking bypass mechanisms that may cause TKI resistance. These alternative strategies of signal transduction therapy may be tested in future trials incorporating in vitro leukemic resistance screens $[127,128]$ determining the value of functional genomics in individualized therapy strategies $[126,127]$.

\section{Acknowledgments}

This study was supported by grants from the Norwegian Cancer Society with Solveig and Ove Lund's legacy. 


\section{Author Contributions}

Caroline Benedicte Nitter Engen performed literature searches and wrote the manuscript. Line Wergeland and Jørn Skavland participated in writing sections of the manuscript. Bjørn Tore Gjertsen conceived, performed literature searches and wrote the manuscript. All authors have edited and approved the final manuscript.

\section{Conflicts of Interest}

Bjørn Tore Gjertsen has received consultant honoraria and grant support from Novartis, and received advisory board honoraria from Clavis Pharma AS, Boehringer Ingelheim GmbH, and BerGenBio AS. The remaining authors have no conflicts of interest to declare.

\section{References}

1. Sant, M.; Allemani, C.; Tereanu, C.; de Angelis, R.; Capocaccia, R.; Visser, O.; Marcos-Gragera, R.; Maynadie, M.; Simonetti, A.; Lutz, J.M.; et al. Incidence of hematologic malignancies in Europe by morphologic subtype: Results of the HAEMACARE project. Blood 2010, 116, 3724-3734.

2. Smith, A.; Howell, D.; Patmore, R.; Jack, A.; Roman, E. Incidence of haematological malignancy by sub-type: A report from the Haematological Malignancy Research Network. Br. J. Cancer 2011, 105, 1684-1692.

3. Estey, E.; Dohner, H. Acute myeloid leukaemia. Lancet 2006, 368, 1894-1907.

4. Roboz, G.J. Current treatment of acute myeloid leukemia. Curr. Opin. Oncol. 2012, 24, 711-719.

5. Dombret, H. Optimal acute myeloid leukemia therapy in 2012. Hematol. Educ.: Educ. Program Annu. Congr. Eur. Hematol. Assoc. 2012, 6, 41-48.

6. Estey, E.H. Acute myeloid leukemia: 2013 update on risk-stratification and management. Am. J. Hematol. 2013, 88, 318-327.

7. Patel, J.P.; Gonen, M.; Figueroa, M.E.; Fernandez, H.; Sun, Z.; Racevskis, J.; van Vlierberghe, P.; Dolgalev, I.; Thomas, S.; Aminova, O.; et al. Prognostic relevance of integrated genetic profiling in acute myeloid leukemia. N. Engl. J. Med. 2012, 366, 1079-1089.

8. Schlenk, R.F.; Dohner, K.; Krauter, J.; Frohling, S.; Corbacioglu, A.; Bullinger, L.; Habdank, M.; Spath, D.; Morgan, M.; Benner, A.; et al. Mutations and treatment outcome in cytogenetically normal acute myeloid leukemia. N. Engl. J. Med. 2008, 358, 1909-1918.

9. Foran, J.M. New prognostic markers in acute myeloid leukemia: Perspective from the clinic. Hematol. Am. Soc. Hematol. Educ. Program. 2010, 2010, 47-55.

10. Marcucci, G.; Haferlach, T.; Dohner, H. Molecular genetics of adult acute myeloid leukemia: Prognostic and therapeutic implications. J. Clin. Oncol. 2011, 29, 475-486.

11. Dohner, H.; Estey, E.H.; Amadori, S.; Appelbaum, F.R.; Buchner, T.; Burnett, A.K.; Dombret, H.; Fenaux, P.; Grimwade, D.; Larson, R.A.; et al. Diagnosis and management of acute myeloid leukemia in adults: Recommendations from an international expert panel, on behalf of the European LeukemiaNet. Blood 2010, 115, 453-474.

12. Grimwade, D. The clinical significance of cytogenetic abnormalities in acute myeloid leukaemia. Best Pract. Res. Clin. Haematol. 2001, 14, 497-529. 
13. Grimwade, D.; Hills, R.K.; Moorman, A.V.; Walker, H.; Chatters, S.; Goldstone, A.H.; Wheatley, K.; Harrison, C.J.; Burnett, A.K.; National Cancer Research Institute Adult Leukaemia Working Group. Refinement of cytogenetic classification in acute myeloid leukemia: Determination of prognostic significance of rare recurring chromosomal abnormalities among 5876 younger adult patients treated in the United Kingdom Medical Research Council trials. Blood 2010, 116, 354-365.

14. Port, M.; Bottcher, M.; Thol, F.; Ganser, A.; Schlenk, R.; Wasem, J.; Neumann, A.; Pouryamout, L. Prognostic significance of FLT3 internal tandem duplication, nucleophosmin 1, and CEBPA gene mutations for acute myeloid leukemia patients with normal karyotype and younger than 60 years: A systematic review and meta-analysis. Ann. Hematol. 2014, 93, 1279-1286.

15. Gutierrez, S.E.; Romero-Oliva, F.A. Epigenetic changes: A common theme in acute myelogenous leukemogenesis. J. Hematol. Oncol. 2013, 6, 57.

16. Shivarov, V.; Bullinger, L. Expression profiling of leukemia patients: Key lessons and future directions. Exp. Hematol. 2014, 42, 651-660.

17. Raaijmakers, M.H. Niche contributions to oncogenesis: Emerging concepts and implications for the hematopoietic system. Haematologica 2011, 96, 1041-1048.

18. Whichard, Z.L.; Sarkar, C.A.; Kimmel, M.; Corey, S.J. Hematopoiesis and its disorders: A systems biology approach. Blood 2010, 115, 2339-2347.

19. The Cancer Genome Atlas Research Network. Genomic and epigenomic landscapes of adult de novo acute myeloid leukemia. N. Engl. J. Med. 2013, 368, 2059-2074.

20. Deininger, M.; Buchdunger, E.; Druker, B.J. The development of imatinib as a therapeutic agent for chronic myeloid leukemia. Blood 2005, 105, 2640-2653.

21. Daver, N.; Cortes, J. Molecular targeted therapy in acute myeloid leukemia. Hematology 2012, 17 (Suppl 1), 59-62.

22. Nakao, M.; Yokota, S.; Iwai, T.; Kaneko, H.; Horiike, S.; Kashima, K.; Sonoda, Y.; Fujimoto, T.; Misawa, S. Internal tandem duplication of the flt3 gene found in acute myeloid leukemia. Leukemia 1996, 10, 1911-1918.

23. Matsuno, N.; Nanri, T.; Kawakita, T.; Mitsuya, H.; Asou, N. A novel FLT3 activation loop mutation $\mathrm{N} 841 \mathrm{~K}$ in acute myeloblastic leukemia. Leukemia 2005, 19, 480-481.

24. Yamamoto, Y.; Kiyoi, H.; Nakano, Y.; Suzuki, R.; Kodera, Y.; Miyawaki, S.; Asou, N.; Kuriyama, K.; Yagasaki, F.; Shimazaki, C.; et al. Activating mutation of D835 within the activation loop of FLT3 in human hematologic malignancies. Blood 2001, 97, 2434-2439.

25. Brasel, K.; Escobar, S.; Anderberg, R.; de Vries, P.; Gruss, H.J.; Lyman, S.D. Expression of the flt3 receptor and its ligand on hematopoietic cells. Leukemia 1995, 9, 1212-1218.

26. Piacibello, W.; Fubini, L.; Sanavio, F.; Brizzi, M.F.; Severino, A.; Garetto, L.; Stacchini, A.; Pegoraro, L.; Aglietta, M. Effects of human FLT3 ligand on myeloid leukemia cell growth: Heterogeneity in response and synergy with other hematopoietic growth factors. Blood 1995, 86, 4105-4114.

27. Drexler, H.G.; Quentmeier, H. FLT3: Receptor and ligand. Growth Factors 2004, 22, 71-73. 
28. Gotze, K.S.; Ramirez, M.; Tabor, K.; Small, D.; Matthews, W.; Civin, C.I. Flt3high and Flt3low CD34+ progenitor cells isolated from human bone marrow are functionally distinct. Blood 1998, 91, 1947-1958.

29. Birg, F.; Courcoul, M.; Rosnet, O.; Bardin, F.; Pebusque, M.J.; Marchetto, S.; Tabilio, A.; Mannoni, P.; Birnbaum, D. Expression of the FMS/KIT-like gene FLT3 in human acute leukemias of the myeloid and lymphoid lineages. Blood 1992, 80, 2584-2593.

30. Carow, C.E.; Levenstein, M.; Kaufmann, S.H.; Chen, J.; Amin, S.; Rockwell, P.; Witte, L.; Borowitz, M.J.; Civin, C.I.; Small, D. Expression of the hematopoietic growth factor receptor FLT3 (STK-1/Flk2) in human leukemias. Blood 1996, 87, 1089-1096.

31. Ozeki, K.; Kiyoi, H.; Hirose, Y.; Iwai, M.; Ninomiya, M.; Kodera, Y.; Miyawaki, S.; Kuriyama, K.; Shimazaki, C.; Akiyama, H.; et al. Biologic and clinical significance of the FLT3 transcript level in acute myeloid leukemia. Blood 2004, 103, 1901-1908.

32. Kiyoi, H.; Naoe, T.; Nakano, Y.; Yokota, S.; Minami, S.; Miyawaki, S.; Asou, N.; Kuriyama, K.; Jinnai, I.; Shimazaki, C.; et al. Prognostic implication of FLT3 and N-RAS gene mutations in acute myeloid leukemia. Blood 1999, 93, 3074-3080.

33. Abu-Duhier, F.M.; Goodeve, A.C.; Wilson, G.A.; Gari, M.A.; Peake, I.R.; Rees, D.C.; Vandenberghe, E.A.; Winship, P.R.; Reilly, J.T. FLT3 internal tandem duplication mutations in adult acute myeloid leukaemia define a high-risk group. Br. J. Haematol. 2000, 111, 190-195.

34. Kottaridis, P.D.; Gale, R.E.; Frew, M.E.; Harrison, G.; Langabeer, S.E.; Belton, A.A.; Walker, H.; Wheatley, K.; Bowen, D.T.; Burnett, A.K.; et al. The presence of a FLT3 internal tandem duplication in patients with acute myeloid leukemia (AML) adds important prognostic information to cytogenetic risk group and response to the first cycle of chemotherapy: Analysis of 854 patients from the United Kingdom Medical Research Council AML 10 and 12 trials. Blood 2001, 98, 1752-1759.

35. Vardiman, J.W.; Thiele, J.; Arber, D.A.; Brunning, R.D.; Borowitz, M.J.; Porwit, A.; Harris, N.L.; le Beau, M.M.; Hellstrom-Lindberg, E.; Tefferi, A.; et al. The 2008 revision of the World Health Organization (WHO) classification of myeloid neoplasms and acute leukemia: Rationale and important changes. Blood 2009, 114, 937-951.

36. Kiyoi, H.; Towatari, M.; Yokota, S.; Hamaguchi, M.; Ohno, R.; Saito, H.; Naoe, T. Internal tandem duplication of the FLT3 gene is a novel modality of elongation mutation which causes constitutive activation of the product. Leukemia 1998, 12, 1333-1337.

37. Kornblau, S.M.; Womble, M.; Qiu, Y.H.; Jackson, C.E.; Chen, W.; Konopleva, M.; Estey, E.H.; Andreeff, M. Simultaneous activation of multiple signal transduction pathways confers poor prognosis in acute myelogenous leukemia. Blood 2006, 108, 2358-2365.

38. Toffalini, F.; Demoulin, J.B. New insights into the mechanisms of hematopoietic cell transformation by activated receptor tyrosine kinases. Blood 2010, 116, 2429-2437.

39. Choudhary, C.; Brandts, C.; Schwable, J.; Tickenbrock, L.; Sargin, B.; Ueker, A.; Bohmer, F.D.; Berdel, W.E.; Muller-Tidow, C.; Serve, H. Activation mechanisms of STAT5 by oncogenic Flt3-ITD. Blood 2007, 110, 370-374.

40. Tse, K.F.; Novelli, E.; Civin, C.I.; Bohmer, F.D.; Small, D. Inhibition of FLT3-mediated transformation by use of a tyrosine kinase inhibitor. Leukemia 2001, 15, 1001-1010. 
41. Levis, M.; Tse, K.F.; Smith, B.D.; Garrett, E.; Small, D. A FLT3 tyrosine kinase inhibitor is selectively cytotoxic to acute myeloid leukemia blasts harboring FLT3 internal tandem duplication mutations. Blood 2001, 98, 885-887.

42. Levis, M.; Allebach, J.; Tse, K.F.; Zheng, R.; Baldwin, B.R.; Smith, B.D.; Jones-Bolin, S.; Ruggeri, B.; Dionne, C.; Small, D. A FLT3-targeted tyrosine kinase inhibitor is cytotoxic to leukemia cells in vitro and in vivo. Blood 2002, 99, 3885-3891.

43. Smith, B.D.; Levis, M.; Beran, M.; Giles, F.; Kantarjian, H.; Berg, K.; Murphy, K.M.; Dauses, T.; Allebach, J.; Small, D. Single-agent CEP-701, a novel FLT3 inhibitor, shows biologic and clinical activity in patients with relapsed or refractory acute myeloid leukemia. Blood 2004, 103, 3669-3676.

44. Knapper, S.; Burnett, A.K.; Littlewood, T.; Kell, W.J.; Agrawal, S.; Chopra, R.; Clark, R.; Levis, M.J.; Small, D. A phase 2 trial of the FLT3 inhibitor lestaurtinib (CEP701) as first-line treatment for older patients with acute myeloid leukemia not considered fit for intensive chemotherapy. Blood 2006, 108, 3262-3270.

45. Levis, M.; Ravandi, F.; Wang, E.S.; Baer, M.R.; Perl, A.; Coutre, S.; Erba, H.; Stuart, R.K.; Baccarani, M.; Cripe, L.D.; et al. Results from a randomized trial of salvage chemotherapy followed by lestaurtinib for patients with FLT3 mutant AML in first relapse. Blood 2011, 117, 3294-3301.

46. Wang, E.S.; Yee, K.; Koh, L.P.; Hogge, D.; Enschede, S.; Carlson, D.M.; Dudley, M.; Glaser, K.; McKeegan, E.; Albert, D.H.; et al. Phase 1 trial of linifanib (ABT-869) in patients with refractory or relapsed acute myeloid leukemia. Leuk Lymphoma 2012, 53, 1543-1551.

47. Stone, R.M.; DeAngelo, D.J.; Klimek, V.; Galinsky, I.; Estey, E.; Nimer, S.D.; Grandin, W.; Lebwohl, D.; Wang, Y.; Cohen, P.; et al. Patients with acute myeloid leukemia and an activating mutation in FLT3 respond to a small-molecule FLT3 tyrosine kinase inhibitor, PKC412. Blood 2005, 105, 54-60.

48. Fischer, T.; Stone, R.M.; Deangelo, D.J.; Galinsky, I.; Estey, E.; Lanza, C.; Fox, E.; Ehninger, G.; Feldman, E.J.; Schiller, G.J.; et al. Phase IIB trial of oral Midostaurin (PKC412), the FMS-like tyrosine kinase 3 receptor (FLT3) and multi-targeted kinase inhibitor, in patients with acute myeloid leukemia and high-risk myelodysplastic syndrome with either wild-type or mutated FLT3. J. Clin. Oncol. 2010, 28, 4339-4345.

49. Stone, R.M.; Fischer, T.; Paquette, R.; Schiller, G.; Schiffer, C.A.; Ehninger, G.; Cortes, J.; Kantarjian, H.M.; DeAngelo, D.J.; Huntsman-Labed, A.; et al. Phase IB study of the FLT3 kinase inhibitor midostaurin with chemotherapy in younger newly diagnosed adult patients with acute myeloid leukemia. Leukemia 2012, 26, 2061-2068.

50. O'Farrell, A.M.; Yuen, H.A.; Smolich, B.; Hannah, A.L.; Louie, S.G.; Hong, W.; Stopeck, A.T.; Silverman, L.R.; Lancet, J.E.; Karp, J.E.; et al. Effects of SU5416, a small molecule tyrosine kinase receptor inhibitor, on FLT3 expression and phosphorylation in patients with refractory acute myeloid leukemia. Leuk. Res. 2004, 28, 679-689.

51. Fiedler, W.; Mesters, R.; Tinnefeld, H.; Loges, S.; Staib, P.; Duhrsen, U.; Flasshove, M.; Ottmann, O.G.; Jung, W.; Cavalli, F.; et al. A phase 2 clinical study of SU5416 in patients with refractory acute myeloid leukemia. Blood 2003, 102, 2763-2767. 
52. Giles, F.J.; Stopeck, A.T.; Silverman, L.R.; Lancet, J.E.; Cooper, M.A.; Hannah, A.L.; Cherrington, J.M.; O'Farrell, A.M.; Yuen, H.A.; Louie, S.G.; et al. SU5416, a small molecule tyrosine kinase receptor inhibitor, has biologic activity in patients with refractory acute myeloid leukemia or myelodysplastic syndromes. Blood 2003, 102, 795-801.

53. Zhang, W.; Konopleva, M.; Shi, Y.X.; McQueen, T.; Harris, D.; Ling, X.; Estrov, Z.; Quintas-Cardama, A.; Small, D.; Cortes, J.; et al. Mutant FLT3: A direct target of sorafenib in acute myelogenous leukemia. J. Natl. Cancer Inst. 2008, 100, 184-198.

54. Crump, M.; Hedley, D.; Kamel-Reid, S.; Leber, B.; Wells, R.; Brandwein, J.; Buckstein, R.; Kassis, J.; Minden, M.; Matthews, J.; et al. A randomized phase I clinical and biologic study of two schedules of sorafenib in patients with myelodysplastic syndrome or acute myeloid leukemia: A NCIC (National Cancer Institute of Canada) Clinical Trials Group Study. Leuk. Lymphoma 2010, 51, 252-260.

55. Serve, H.; Krug, U.; Wagner, R.; Sauerland, M.C.; Heinecke, A.; Brunnberg, U.; Schaich, M.; Ottmann, O.; Duyster, J.; Wandt, H.; et al. Sorafenib in combination with intensive chemotherapy in elderly patients with acute myeloid leukemia: Results from a randomized, placebo-controlled trial. J. Clin. Oncol. 2013, 31, 3110-3118.

56. Inaba, H.; Rubnitz, J.E.; Coustan-Smith, E.; Li, L.; Furmanski, B.D.; Mascara, G.P.; Heym, K.M.; Christensen, R.; Onciu, M.; Shurtleff, S.A.; et al. Phase I pharmacokinetic and pharmacodynamic study of the multikinase inhibitor sorafenib in combination with clofarabine and cytarabine in pediatric relapsed/refractory leukemia. J. Clin. Oncol. 2011, 29, 3293-3300.

57. Ravandi, F.; Alattar, M.L.; Grunwald, M.R.; Rudek, M.A.; Rajkhowa, T.; Richie, M.A.; Pierce, S.; Daver, N.; Garcia-Manero, G.; Faderl, S.; et al. Phase 2 study of azacytidine plus sorafenib in patients with acute myeloid leukemia and FLT-3 internal tandem duplication mutation. Blood 2013, 121, 4655-4662.

58. O’Farrell, A.M.; Foran, J.M.; Fiedler, W.; Serve, H.; Paquette, R.L.; Cooper, M.A.; Yuen, H.A.; Louie, S.G.; Kim, H.; Nicholas, S.; et al. An innovative phase I clinical study demonstrates inhibition of FLT3 phosphorylation by SU11248 in acute myeloid leukemia patients. Clin. Cancer Res. 2003, 9, 5465-5476.

59. Fiedler, W.; Serve, H.; Dohner, H.; Schwittay, M.; Ottmann, O.G.; O'Farrell, A.M.; Bello, C.L.; Allred, R.; Manning, W.C.; Cherrington, J.M.; et al. A phase 1 study of SU11248 in the treatment of patients with refractory or resistant acute myeloid leukemia (AML) or not amenable to conventional therapy for the disease. Blood 2005, 105, 986-993.

60. DeAngelo, D.J.; Stone, R.M.; Heaney, M.L.; Nimer, S.D.; Paquette, R.L.; Klisovic, R.B.; Caligiuri, M.A.; Cooper, M.R.; Lecerf, J.M.; Karol, M.D.; et al. Phase 1 clinical results with tandutinib (MLN518), a novel FLT3 antagonist, in patients with acute myelogenous leukemia or high-risk myelodysplastic syndrome: Safety, pharmacokinetics, and pharmacodynamics. Blood 2006, 108, 3674-3681.

61. Cortes, J.; Foran, J.; Ghirdaladze, D.; DeVetten, M.P.; Zodelava, M.; Holman, P.; Levis, M.J.; Kantarjian, H.M.; Borthakur, G.; James, J.; et al. AC220, a Potent, Selective, Second Generation FLT3 Receptor Tyrosine Kinase (RTK) Inhibitor, in a First-in-Human (FIH) Phase 1 AML Study. Blood (ASH Annual Meeting Abstracts) 2009, 114, 636. 
62. Cortes, J.E.; Tallman, M.S.; Schiller, G.; Trone, D.; Gammon, G.; Goldberg, S.; Perl, A.E.; Marie, J.P.; Martelli, G.; Levis, M. Results of a Phase 2 Randomized, Open-Label, Study of Lower Doses of Quizartinib (AC220; ASP2689) in Subjects With FLT3-ITD Positive Relapsed or Refractory Acute Myeloid Leukemia (AML). Blood (ASH Annual Meeting Abstracts) 2013, 122, 494.

63. Levis, M.J.; Perl, A.E.; Dombret, H.; Döhner, H.; Steffen, B.; Rousselot, P.; Martinelli, G.; Estey, E.H.; Burnett, A.K.; Gammon, G.; et al. Final Results of a Phase 2 Open-Label, Monotherapy Efficacy and Safety Study of Quizartinib (AC220) in Patients with FLT3-ITD Positive or Negative Relapsed/Refractory Acute Myeloid Leukemia After Second-Line Chemotherapy or Hematopoietic Stem Cell Transplantation. Blood (ASH Annual Meeting Abstracts) 2012, 120, 673.

64. Cortes, J.E.; Perl, A.E.; Dombret, H.; Kayser, S.; Steffen, B.; Rousselot, P.; Martinelli, G.; Estey, E.H.; Burnett, A.K.; Gammon, G.; et al. Final Results of a Phase 2 Open-Label, Monotherapy Efficacy and Safety Study of Quizartinib (AC220) in Patients 60 Years of Age with FLT3 ITD Positive or Negative Relapsed/Refractory Acute Myeloid Leukemia. Blood (ASH Annual Meeting Abstracts) 2012, 120, 46.

65. Burnett, A.K.; Bowen, D.; Russell, N.; Knapper, S.; Milligan, D.; Hunter, A.E.; Khwaja, A.; Clark, R.E.; Culligan, D.; Clark, H.; et al. AC220 (Quizartinib) Can be Safely Combined with Conventional Chemotherapy in Older Patients with Newly Diagnosed Acute Myeloid Leukaemia: Experience from the AML18 Pilot Trial. Blood 2013, 122, 622.

66. Cooper, T.M.; Malvar, J.; Cassar, J.; Eckroth, E.; Sposto, R.; Gaynon, P.; Dubois, S.; Gore, L.; Macy, M.E.; August, K. A Phase I Study of AC220 (Quizartinib) in Combination with Cytarabine and Etoposide in Relapsed/Refractory Childhood ALL and AML: A Therapeutic Advances in Childhood Leukemia \& Lymphoma (TACL) Study. Blood 2013, 122, 624.

67. Shankar, D.B.; Li, J.; Tapang, P.; Owen McCall, J.; Pease, L.J.; Dai, Y.; Wei, R.Q.; Albert, D.H.; Bouska, J.J.; Osterling, D.J.; et al. ABT-869, a multitargeted receptor tyrosine kinase inhibitor: Inhibition of FLT3 phosphorylation and signaling in acute myeloid leukemia. Blood 2007, 109, 3400-3408.

68. Weisberg, E.; Boulton, C.; Kelly, L.M.; Manley, P.; Fabbro, D.; Meyer, T.; Gilliland, D.G.; Griffin, J.D. Inhibition of mutant FLT3 receptors in leukemia cells by the small molecule tyrosine kinase inhibitor PKC412. Cancer Cell 2002, 1, 433-443.

69. Stone, R.M.; de Angelo, J.; Galinsky, I.; Estey, E.; Klimek, V.; Grandin, W.; Lebwohl, D.; Yap, A.; Cohen, P.; Fox, E.; et al. PKC 412 FLT3 inhibitor therapy in AML: Results of a phase II trial. Ann. Hematol. 2004, 83 (Suppl 1), 89-90.

70. Strati, P.; Kantarjian, H.M.; Nazha, A.; Borthakur, G.; Daver, N.G.; Kadia, T.M.; Estrov, Z.; Garcia-Manero, G.; Rajkhowa, T.; Ravandi, F.; et al. Early Results of a Phase I/II Trial of Midostaurin (PKC412) and 5-Azacytidine (5-AZA) for Patients (Pts) with Acute Myeloid Leukemia and Myelodysplastic Syndrome. Blood (ASH Annual Meeting Abstracts) 2013, 122, 3949. 
71. Walker, A.R.; Wang, H.; Klisovic, R.; Walsh, K.; Vasu, S.; Garzon, R.; Devine, S.M.; Drake, A.; Blum, W.; Marcucci, G. Phase I Study of The Combination of Midostaurin, Bortezomib and Chemotherapy in Relapsed/Refractory Acute Myeloid Leukemia (AML): Targeting Aberrant Tyrosine Kinase Activity. Blood (ASH Annual Meeting Abstracts) 2013, 122, 3966.

72. Yee, K.W.; O'Farrell, A.M.; Smolich, B.D.; Cherrington, J.M.; McMahon, G.; Wait, C.L.; McGreevey, L.S.; Griffith, D.J.; Heinrich, M.C. SU5416 and SU5614 inhibit kinase activity of wild-type and mutant FLT3 receptor tyrosine kinase. Blood 2002, 100, 2941-2949.

73. Auclair, D.; Miller, D.; Yatsula, V.; Pickett, W.; Carter, C.; Chang, Y.; Zhang, X.; Wilkie, D.; Burd, A.; Shi, H.; et al. Antitumor activity of sorafenib in FLT3-driven leukemic cells. Leukemia 2007, 21, 439-445.

74. Uy, G.L.; Sandford, B.; Marcucci, G.; Zhao, W.; Geyer, S.; Keplin, H.; Powell, B.L.; Baer, M.R.; Stock, W.; Stone, R.; et al. Initial Results of a Phase II Trial of Sorafenib Plus Standard Induction in Older Adults With Mutant FLT3 Acute Myeloid Leukemia (AML) (Alliance trial C11001). Blood (ASH Annual Meeting Abstracts) 2013, 122, 2653.

75. Pollard, J.; Chang, B.H.; Cooper, T.M.; Gross, T.; Gupta, S.; Ho, P.A.; McGlodrick, S.M.; Watt, T.C. Sorafenib Treatment Following Hematopoietic Stem Cell Transplant in Pediatric FLT3/ITD+ AML. Blood 2013, 122, 3969.

76. O’Farrell, A.M.; Abrams, T.J.; Yuen, H.A.; Ngai, T.J.; Louie, S.G.; Yee, K.W.; Wong, L.M.; Hong, W.; Lee, L.B.; Town, A.; et al. SU11248 is a novel FLT3 tyrosine kinase inhibitor with potent activity in vitro and in vivo. Blood 2003, 101, 3597-3605.

77. Griswold, I.J.; Shen, L.J.; la Rosee, P.; Demehri, S.; Heinrich, M.C.; Braziel, R.M.; McGreevey, L.; Haley, A.D.; Giese, N.; Druker, B.J.; et al. Effects of MLN518, a dual FLT3 and KIT inhibitor, on normal and malignant hematopoiesis. Blood 2004, 104, 2912-2918.

78. Zarrinkar, P.P.; Gunawardane, R.N.; Cramer, M.D.; Gardner, M.F.; Brigham, D.; Belli, B.; Karaman, M.W.; Pratz, K.W.; Pallares, G.; Chao, Q.; et al. AC220 is a uniquely potent and selective inhibitor of FLT3 for the treatment of acute myeloid leukemia (AML). Blood 2009, 114, 2984-2992.

79. Levis, M.; Brown, P.; Smith, B.D.; Stine, A.; Pham, R.; Stone, R.; Deangelo, D.; Galinsky, I.; Giles, F.; Estey, E.; et al. Plasma inhibitory activity (PIA): A pharmacodynamic assay reveals insights into the basis for cytotoxic response to FLT3 inhibitors. Blood 2006, 108, 3477-3483.

80. Weisberg, E.; Sattler, M.; Ray, A.; Griffin, J.D. Drug resistance in mutant FLT3-positive AML. Oncogene 2010, 29, 5120-5134.

81. Heidary, D.K.; Huang, G.; Boucher, D.; Ma, J.; Forster, C.; Grey, R.; Xu, J.; Arnost, M.; Choquette, D.; Chen, G.; et al. VX-322: A novel dual receptor tyrosine kinase inhibitor for the treatment of acute myelogenous leukemia. J. Med. Chem. 2012, 55, 725-734.

82. Lin, W.H.; Jiaang, W.T.; Chen, C.W.; Yen, K.J.; Hsieh, S.Y.; Yen, S.C.; Chen, C.P.; Chang, K.Y.; Chang, C.Y.; Chang, T.Y.; et al. BPR1J-097, a novel FLT3 kinase inhibitor, exerts potent inhibitory activity against AML. Br. J. Cancer 2012, 106, 475-481.

83. Ma, H.S.; Nguyen, B.; Duffield, A.S.; Li, L.; Galanis, A.; Williams, A.B.; Brown, P.A.; Levis, M.J.; Leahy, D.J.; Small, D. FLT3 Kinase Inhibitor TTT-3002 Overcomes both Activating and Drug Resistance Mutations in FLT3 in Acute Myeloid Leukemia. Cancer Res. 2014, 74, 5206-5217. 
84. Ma, H.; Nguyen, B.; Li, L.; Greenblatt, S.; Williams, A.; Zhao, M.; Levis, M.; Rudek, M.; Duffield, A.; Small, D. TTT-3002 is a novel FLT3 tyrosine kinase inhibitor with activity against FLT3-associated leukemias in vitro and in vivo. Blood 2014, 123, 1525-1534.

85. Eriksson, A.; Hoglund, M.; Lindhagen, E.; Aleskog, A.; Hassan, S.B.; Ekholm, C.; Fholenhag, K.; Jensen, A.J.; Lothgren, A.; Scobie, M.; et al. Identification of AKN-032, a novel 2-aminopyrazine tyrosine kinase inhibitor, with significant preclinical activity in acute myeloid leukemia. Biochem. Pharmacol. 2010, 80, 1507-1516.

86. Eriksson, A.; Hermanson, M.; Wickstrom, M.; Lindhagen, E.; Ekholm, C.; Jenmalm Jensen, A.; Lothgren, A.; Lehmann, F.; Larsson, R.; Parrow, V.; et al. The novel tyrosine kinase inhibitor AKN-028 has significant antileukemic activity in cell lines and primary cultures of acute myeloid leukemia. Blood Cancer J. 2012, 2, e81.

87. Alvarado, Y.; Kantarjian, H.M.; Luthra, R.; Ravandi, F.; Borthakur, G.; Garcia-Manero, G.; Konopleva, M.; Estrov, Z.; Andreeff, M.; Cortes, J.E. Treatment with FLT3 inhibitor in patients with FLT3-mutated acute myeloid leukemia is associated with development of secondary FLT3-tyrosine kinase domain mutations. Cancer 2014, 120, 2142-2149.

88. Albers, C.; Leischner, H.; Verbeek, M.; Yu, C.; Illert, A.L.; Peschel, C.; von Bubnoff, N.; Duyster, J. The secondary FLT3-ITD F691L mutation induces resistance to AC220 in FLT3-ITD(+) AML but retains in vitro sensitivity to PKC412 and Sunitinib. Leukemia 2013, doi:10.1038/leu.2013.14.

89. Knapper, S.; Mills, K.I.; Gilkes, A.F.; Austin, S.J.; Walsh, V.; Burnett, A.K. The effects of lestaurtinib (CEP701) and PKC412 on primary AML blasts: The induction of cytotoxicity varies with dependence on FLT3 signaling in both FLT3-mutated and wild-type cases. Blood 2006, 108, 3494-3503.

90. Siendones, E.; Barbarroja, N.; Torres, L.A.; Buendia, P.; Velasco, F.; Dorado, G.; Torres, A.; Lopez-Pedrera, C. Inhibition of Flt3-activating mutations does not prevent constitutive activation of ERK/Akt/STAT pathways in some AML cells: A possible cause for the limited effectiveness of monotherapy with small-molecule inhibitors. Hematol. Oncol. 2007, 25, 30-37.

91. Piloto, O.; Wright, M.; Brown, P.; Kim, K.T.; Levis, M.; Small, D. Prolonged exposure to FLT3 inhibitors leads to resistance via activation of parallel signaling pathways. Blood 2007, 109, 1643-1652.

92. Nybakken, G.E.; Watt, C.; Morrissette, J.J.D.; Bagg, A.; Carroll, M.; Perl, A.E. Diverse Histopathologic and Molecular Responses of Acute Myeloid Leukemia to the FLT3 Inhibitor Quizartinib (AC220). Blood (ASH Annual Meeting Abstracts) 2012, 120, 885.

93. Schaab, C.; Oppermann, F.; Pfeifer, H.; Klammer, M.; Tebbe, A.; Oellerich, T.; Krauter, J.; Levis, M.J.; Perl, A.E.; Daub, H.; et al. Global Phosphoproteome Analysis of AML Bone Marrow Reveals Predictive Markers for the Treatment with AC220. Blood (ASH Annual Meeting Abstracts) 2012, 120, 786.

94. Skavland, J.; Jorgensen, K.M.; Hadziavdic, K.; Hovland, R.; Jonassen, I.; Bruserud, O.; Gjertsen, B.T. Specific cellular signal-transduction responses to in vivo combination therapy with ATRA, valproic acid and theophylline in acute myeloid leukemia. Blood Cancer J. 2011, 1, e4. 
95. Hovland, R.; Gjertsen, B.T.; Bruserud, O. Acute myelogenous leukemia with internal tandem duplication of the Flt3 gene appearing or altering at the time of relapse: A report of two cases. Leuk Lymphoma 2002, 43, 2027-2029.

96. Nazha, A.; Cortes, J.; Faderl, S.; Pierce, S.; Daver, N.; Kadia, T.; Borthakur, G.; Luthra, R.; Kantarjian, H.; Ravandi, F. Activating internal tandem duplication mutations of the fms-like tyrosine kinase-3 (FLT3-ITD) at complete response and relapse in patients with acute myeloid leukemia. Haematologica 2012, 97, 1242-1245.

97. Nakano, Y.; Kiyoi, H.; Miyawaki, S.; Asou, N.; Ohno, R.; Saito, H.; Naoe, T. Molecular evolution of acute myeloid leukaemia in relapse: Unstable N-ras and FLT3 genes compared with p53 gene. Br. J. Haematol. 1999, 104, 659-664.

98. Shih, L.Y.; Huang, C.F.; Wu, J.H.; Lin, T.L.; Dunn, P.; Wang, P.N.; Kuo, M.C.; Lai, C.L.; Hsu, H.C. Internal tandem duplication of FLT3 in relapsed acute myeloid leukemia: A comparative analysis of bone marrow samples from 108 adult patients at diagnosis and relapse. Blood 2002, 100, 2387-2392.

99. Kottaridis, P.D.; Gale, R.E.; Langabeer, S.E.; Frew, M.E.; Bowen, D.T.; Linch, D.C. Studies of FLT3 mutations in paired presentation and relapse samples from patients with acute myeloid leukemia: Implications for the role of FLT3 mutations in leukemogenesis, minimal residual disease detection, and possible therapy with FLT3 inhibitors. Blood 2002, 100, 2393-2398.

100. Koszarska, M.; Meggyesi, N.; Bors, A.; Batai, A.; Csacsovszki, O.; Lehoczky, E.; Adam, E.; Kozma, A.; Lovas, N.; Sipos, A.; et al. Medium-sized FLT3 internal tandem duplications confer worse prognosis than short and long duplications in a non-elderly acute myeloid leukemia cohort. Leuk Lymphoma 2014, 55, 1510-1517.

101. Stirewalt, D.L.; Kopecky, K.J.; Meshinchi, S.; Engel, J.H.; Pogosova-Agadjanyan, E.L.; Linsley, J.; Slovak, M.L.; Willman, C.L.; Radich, J.P. Size of FLT3 internal tandem duplication has prognostic significance in patients with acute myeloid leukemia. Blood 2006, 107, 3724-3726.

102. Gale, R.E.; Green, C.; Allen, C.; Mead, A.J.; Burnett, A.K.; Hills, R.K.; Linch, D.C.; Medical Research Council Adult Leukaemia Working Party. The impact of FLT3 internal tandem duplication mutant level, number, size, and interaction with NPM1 mutations in a large cohort of young adult patients with acute myeloid leukemia. Blood 2008, 111, 2776-2784.

103. Whitman, S.P.; Archer, K.J.; Feng, L.; Baldus, C.; Becknell, B.; Carlson, B.D.; Carroll, A.J.; Mrozek, K.; Vardiman, J.W.; George, S.L.; et al. Absence of the wild-type allele predicts poor prognosis in adult de novo acute myeloid leukemia with normal cytogenetics and the internal tandem duplication of FLT3: A cancer and leukemia group B study. Cancer Res. 2001, 61, $7233-7239$.

104. Kayser, S.; Schlenk, R.F.; Londono, M.C.; Breitenbuecher, F.; Wittke, K.; Du, J.; Groner, S.; Spath, D.; Krauter, J.; Ganser, A.; et al. Insertion of FLT3 internal tandem duplication in the tyrosine kinase domain-1 is associated with resistance to chemotherapy and inferior outcome. Blood 2009, 114, 2386-2392.

105. Borthakur, G.; Kantarjian, H.; Patel, K.P.; Ravandi, F.; Qiao, W.; Faderl, S.; Kadia, T.; Luthra, R.; Pierce, S.; Cortes, J.E. Impact of numerical variation in FMS-like tyrosine kinase receptor 3 internal tandem duplications on clinical outcome in normal karyotype acute myelogenous leukemia. Cancer 2012, 118, 5819-5822. 
106. Ley, T.J.; Mardis, E.R.; Ding, L.; Fulton, B.; McLellan, M.D.; Chen, K.; Dooling, D.; Dunford-Shore, B.H.; McGrath, S.; Hickenbotham, M.; et al. DNA sequencing of a cytogenetically normal acute myeloid leukaemia genome. Nature 2008, 456, 66-72.

107. Welch, J.S.; Ley, T.J.; Link, D.C.; Miller, C.A.; Larson, D.E.; Koboldt, D.C.; Wartman, L.D.; Lamprecht, T.L.; Liu, F.; Xia, J.; et al. The origin and evolution of mutations in acute myeloid leukemia. Cell 2012, 150, 264-278.

108. Ding, L.; Ley, T.J.; Larson, D.E.; Miller, C.A.; Koboldt, D.C.; Welch, J.S.; Ritchey, J.K.; Young, M.A.; Lamprecht, T.; McLellan, M.D.; et al. Clonal evolution in relapsed acute myeloid leukaemia revealed by whole-genome sequencing. Nature 2012, 481, 506-510.

109. Corces-Zimmerman, M.R.; Hong, W.J.; Weissman, I.L.; Medeiros, B.C.; Majeti, R. Preleukemic mutations in human acute myeloid leukemia affect epigenetic regulators and persist in remission. Proc. Natl. Acad. Sci. USA 2014, 111, 2548-2553.

110. Shlush, L.I.; Zandi, S.; Mitchell, A.; Chen, W.C.; Brandwein, J.M.; Gupta, V.; Kennedy, J.A.; Schimmer, A.D.; Schuh, A.C.; Yee, K.W.; et al. Identification of pre-leukaemic haematopoietic stem cells in acute leukaemia. Nature 2014, 506, 328-333.

111. Shih, L.Y.; Huang, C.F.; Wang, P.N.; Wu, J.H.; Lin, T.L.; Dunn, P.; Kuo, M.C. Acquisition of FLT3 or N-ras mutations is frequently associated with progression of myelodysplastic syndrome to acute myeloid leukemia. Leukemia 2004, 18, 466-475.

112. Horiike, S.; Yokota, S.; Nakao, M.; Iwai, T.; Sasai, Y.; Kaneko, H.; Taniwaki, M.; Kashima, K.; Fujii, H.; Abe, T.; et al. Tandem duplications of the FLT3 receptor gene are associated with leukemic transformation of myelodysplasia. Leukemia 1997, 11, 1442-1446.

113. Ostronoff, F.; Othus, M.; Gerbing, R.B.; Loken, M.R.; Raimondi, S.C.; Hirsch, B.A.; Lange, B.J.; Petersdorf, S.; Radich, J.; Appelbaum, F.R.; et al. Co-expression of NUP98/NSD1 and FLT3/ITD is more prevalent in younger AML patients and leads to high-risk of induction failure: A COG and SWOG report. Blood 2014, 124, 2400-2407.

114. Kelly, L.M.; Kutok, J.L.; Williams, I.R.; Boulton, C.L.; Amaral, S.M.; Curley, D.P.; Ley, T.J.; Gilliland, D.G. PML/RARalpha and FLT3-ITD induce an APL-like disease in a mouse model. Proc. Natl. Acad. Sci. USA 2002, 99, 8283-8288.

115. Godfrey, R.; Arora, D.; Bauer, R.; Stopp, S.; Muller, J.P.; Heinrich, T.; Bohmer, S.A.; Dagnell, M.; Schnetzke, U.; Scholl, S.; et al. Cell transformation by FLT3 ITD in acute myeloid leukemia involves oxidative inactivation of the tumor suppressor protein-tyrosine phosphatase DEP-1/ PTPRJ. Blood 2012, 119, 4499-4511.

116. Park, I.K.; Mishra, A.; Chandler, J.; Whitman, S.P.; Marcucci, G.; Caligiuri, M.A. Inhibition of the receptor tyrosine kinase Axl impedes activation of the FLT3 internal tandem duplication in human acute myeloid leukemia: Implications for Axl as a potential therapeutic target. Blood 2013, doi:10.1182/blood-2012-07-444018.

117. Chapuis, N.; Tamburini, J.; Green, A.S.; Vignon, C.; Bardet, V.; Neyret, A.; Pannetier, M.; Willems, L.; Park, S.; Macone, A.; et al. Dual inhibition of PI3K and mTORC1/2 signaling by NVP-BEZ235 as a new therapeutic strategy for acute myeloid leukemia. Clin. Cancer Res. 2010, $16,5424-5435$. 
118. Ricciardi, M.R.; Scerpa, M.C.; Bergamo, P.; Ciuffreda, L.; Petrucci, M.T.; Chiaretti, S.; Tavolaro, S.; Mascolo, M.G.; Abrams, S.L.; Steelman, L.S.; et al. Therapeutic potential of MEK inhibition in acute myelogenous leukemia: Rationale for "vertical" and "lateral" combination strategies. J Mol Med (Berl) 2012, 90, 1133-1144.

119. Koch, S.; Jacobi, A.; Ryser, M.; Ehninger, G.; Thiede, C. Abnormal localization and accumulation of FLT3-ITD, a mutant receptor tyrosine kinase involved in leukemogenesis. Cells Tissues Organs 2008, 188, 225-235.

120. Schmidt-Arras, D.; Bohmer, S.A.; Koch, S.; Muller, J.P.; Blei, L.; Cornils, H.; Bauer, R.; Korasikha, S.; Thiede, C.; Bohmer, F.D. Anchoring of FLT3 in the endoplasmic reticulum alters signaling quality. Blood 2009, 113, 3568-3576.

121. D'Incalci, M.; Capranico, G.; Giaccone, G.; Zunino, F.; Garattini, S. DNA topoisomerase inhibitors. Cancer Chemother. Biol. Response Modif. 1993, 14, 61-85.

122. Bilardi, R.A.; Kimura, K.I.; Phillips, D.R.; Cutts, S.M. Processing of anthracycline-DNA adducts via DNA replication and interstrand crosslink repair pathways. Biochem. Pharmacol. 2012, 83, 1241-1250.

123. Fernandez, H.F.; Sun, Z.; Yao, X.; Litzow, M.R.; Luger, S.M.; Paietta, E.M.; Racevskis, J.; Dewald, G.W.; Ketterling, R.P.; Bennett, J.M.; et al. Anthracycline dose intensification in acute myeloid leukemia. N. Engl. J. Med. 2009, 361, 1249-1259.

124. Pardee, T.S.; Zuber, J.; Lowe, S.W. Flt3-ITD alters chemotherapy response in vitro and in vivo in a p53-dependent manner. Exp. Hematol. 2011, 39, 473-485.

125. Zhao, R.; Yang, F.T.; Alexander, D.R. An oncogenic tyrosine kinase inhibits DNA repair and DNA-damage-induced Bcl-xL deamidation in T cell transformation. Cancer Cell 2004, 5, 37-49.

126. Sallmyr, A.; Fan, J.; Datta, K.; Kim, K.T.; Grosu, D.; Shapiro, P.; Small, D.; Rassool, F. Internal tandem duplication of FLT3 (FLT3/ITD) induces increased ROS production, DNA damage, and misrepair: Implications for poor prognosis in AML. Blood 2008, 111, 3173-3182.

127. Heckman, C.A.; Kontro, M.; Pemovska, T.; Eldfors, S.; Edgren, H.; Kulesskiy, E.; Majumder, M.M.; Karjalainen, R.; Yadav, B.; Szwajda, A.; et al. High-Throughput ex Vivo Drug Sensitivity and Resistance Testing (DSRT) Integrated with Deep Genomic and Molecular Profiling Reveal New Therapy Options with Targeted Drugs in Subgroups of Relapsed Chemorefractory AML. Blood (ASH Annual Meeting Abstracts) 2012, 2012, 288.

128. Dishing out cancer treatment. Nat. Biotechnol. 2013, 31, 85.

(C) 2014 by the authors; licensee MDPI, Basel, Switzerland. This article is an open access article distributed under the terms and conditions of the Creative Commons Attribution license (http://creativecommons.org/licenses/by/4.0/). 